\title{
KADAR HORMON LH BASAL SEBAGAI PREDIKTOR KEBERHASILAN STIMULASI OVARIUM PADA PROGRAM BAYI TABUNG
}

\author{
Dyah Ariyantini ${ }^{1}$, M. Lutfi ${ }^{2}$, Diah Rumekti Hadiati ${ }^{3}$
}

\begin{abstract}
Background: Ovarian stimulation is part of assisted reproductive technology (ART) process, which aims to spur the growth of follicles to be developed, so that it will increase the chance of getting pregnant. LH surge cause the final follicular maturation, ovulation and becoming corpus luteum. So that an increase in LH may adversely affect the development of the follicle and eventually affect in-vitro fertilization.

Objective To determine the effect of basal LH hormone to follicles on the stimulation of ovarian.
\end{abstract}

Method: Cohort Retrospective.

Research Location: Permata Hati Clinic of Sardjito Hospital, Yogyakarta

Result dan Discussion: The study included 70 cycles of 70 women who underwent ovarian stimulation for in-vitro fertilization and fulfill inclusion and exclusion criterias. The subjects were divided into 2 groups based on basal LH hormone levels i.e. $\mathrm{LH} \leq 3 \mathrm{mIU} / \mathrm{ml}$ as the test group and $\mathrm{LH}>3 \mathrm{mIU} / \mathrm{ml}$ as the control group. From analysis, response to ovarian stimulation in group with $\mathrm{LH} \leq 3 \mathrm{mlU} / \mathrm{ml}$ was significantly different than $\mathrm{LH}>3 \mathrm{mlU} / \mathrm{ml}$ (RR 1,875; $95 \% \mathrm{Cl} 1,275-2,757 ; \mathrm{p}=0,00 *$ ).

Conclusion: Low level of basal LH ( $\leq 3 \mathrm{mIU} / \mathrm{ml}$ ) generating fewer number of mature follicles in patients who performed ovarian stimulation in in-vitro fertilization program.

Keyword: basal LH, ovarian stimulation, in-vitro fertilization.

\begin{abstract}
ABSTRAK
Latar Belakang: Stimulasi ovarium merupakan bagian dari program Teknologi Reproduksi Berbantu (TRB) yang mempunyai tujuan untuk memacu pertumbuhan folikel menjadi berkembang sehingga akan meningkatkan kesempatan untuk hamil. LH surge menyebabkan pematangan folikel akhir, ovulasi dan pembentukan korpus luteum. Peningkatan LH dapat berpengaruh buruk terhadap perkembangan folikel dan akhirnya mempengaruhi fertilisasi in-vitro.
\end{abstract}

Tujuan: Untuk mengetahui pengaruh hormon LH basal terhadap respon stimulasi ovarium pada program fertilisasi in vitro.

Metode: Kohort retrospektif.

Tempat penelitian: Klinik Permata Hati RSUP Dr. Sardjito Yogyakarta.

Hasil dan Pembahasan: Penelitian melibatkan 70 siklus dari 70 pasangan yang menjalani fertilisasi in-vitro yang dimasukkan dalam penelitian sesuai dengan kriteria inklusi dan eksklusi. Dengan cut off point LH basal ditetapkan $3 \mathrm{mlU} / \mathrm{ml}$, maka subyek ini dibagi menjadi 2 kelompok yaitu $\leq 3 \mathrm{mIU} / \mathrm{ml}$ sebagai kelompok uji dan $>3 \mathrm{mIU} / \mathrm{ml}$ sebagai kelompok kontrol. Terdapat perbedaan bermakna antara respon stimulasi ovarium pada kelompok LH basal $\leq 3 \mathrm{mIU} / \mathrm{ml}$ dan LH basal >3 mlU/ml (RR 1,875; IK 95\% 1,275-2,757; $p=0,00 *$ ).

1,2,3 Departemen Obstetri dan Ginekologi FKKMK UGM 
Kesimpulan: Kadar hormon LH basal yang rendah ( $\leq 3 \mathrm{mIU} / \mathrm{ml}$ ) menghasilkan respon yang lebih buruk pada pasien yang dikerjakan stimulasi ovarium pada program fertilisasi in vitro.

Kata kunci: LH basal, stimulasi ovarium, fertilisasi in-vitro

\section{PENDAHULUAN}

Stimulasi ovarium merupakan bagian dari program Teknologi Reproduksi Berbantu (TRB) yang mempunyai tujuan untuk memacu pertumbuhan folikel menjadi berkembang sehingga akan meningkatkan kesempatan untuk hamil. Meskipun terdapat beberapa faktor yang mempengaruhi, respon ovarium terhadap stimulasi merupakan faktor utama yang menentukan keberhasilan program dan dipengaruhi oleh jumlah cadangan folikel di ovarium itu sendiri. Oleh karena itu dibutuhkan suatu alat yang dapat digunakan untuk memprediksi keberhasilan dari stimulasi ovarium tersebut. ${ }^{1}$

Untuk pertumbuhan dan pematangan folikel, serta untuk terjadinya ovulasi dibutuhkan Follicle Stimulating Hormone (FSH) dan Luteinizing Hormone (LH) yang disekresi oleh hipofisis yang dipengaruhi oleh Gonadotropin Releasing Hormone (GnRH) yang disekresi oleh hipotalamus. Hormon basal tubuh sendiri meliputi FSH, LH dan estradiol (E2) dapat diukur pada hari kedua sampai empat dari siklus menstruasi sehingga dapat digunakan untuk memprediksi keberhasilan stimulasi ovarium pada program fertilisasi in vitro.

Hasil stimulasi ovarium terhadap Fertilisasi in vitro (FIV) menunjukkan bahwa LH memegang peranan penting dalam tahap akhir perkembangan folikel, mempengaruhi maturasi folikel dan fungsi folikel dominan. Karena itu, adanya LH dalam folikel sebelum ovulasi merupakan kontributor penting bagi perkembangan folikuler yang optimal yang akhirnya menghasilkan sebuah oosit yang sehat. ${ }^{2}$
Serum basal LH yang $<3 \mathrm{mlU} / \mathrm{ml}$ dapat digunakan untuk memprediksi penurunan respon dari stimulasi ovarium sebagai akibat dari penurunan estradiol puncak dan jumlah folikel preovulatori yang rendah. Hal ini dikarenakan kadar LH yang rendah pada fase folikuler dapat menurunkan aktifitas pengaturan ovarium seperti steroid atau protein seperti inhibin, aktivin, folistin atau insulin-like growth factors dan dapat mempengaruhi perkembangan folikel melalui aksi autokrin atau parakrin. ${ }^{3}$

Tujuan penelitian ini adalah untuk mengetahui pengaruh hormon LH basal terhadap stimulasi ovarium pada program fertilisasi in vitro.

\section{METODE}

Jenis penelitian ini adalah analitik observasional dengan rancangan penelitian kohort retrospektif. Penelitian dilaksanakan dilaksanakan pada bulan Januari sampai bulan Juni 2013 dengan lokasi di Klinik Infertilitas Permata Hati RSUP Dr. Sardjito Yogyakarta. Populasinya adalah semua pasien wanita yang menjalani stimulasi ovarium dalam program Fertilisasi in vitro (FIV). Kriteria inklusi yaitu wanita yang mengikuti program stimulasi ovarium menggunakan gonadotropin dalam program FIV. Kriteria eksklusi adalah subyek yang menghentikan program atau drop out dan data rekam medis yang tidak lengkap. Jumlah sampel pada penelitian ini adalah 70 subyek, dengan 35 subyek pada kelompok LH rendah dan 35 subyek pada kelompok tinggi. Subyek dipilih secara random (tiap kelompok), dari rekam medik pasien yang menjalani program FIV di Klinik Permata Hati RSUP Dr. Sardjito di Yogyakarta pada tahun 2011 sampai tahun 2012. 
Variabel bebas adalah kadar hormon $\mathrm{LH}$ basal dengan cut off point adalah $3 \mathrm{mlU} / \mathrm{ml}$. Variabel tergantung adalah respon ovarium (baik atau buruk). Variabel luar adalah indeks massa tubuh, kadar FSH basal, kadar E2 basal, protokol stimulasi, dosis dan durasi gonadotropin yang digunakan, pasien sindroma ovarium polikistik dan pasien endometriosis grade 3-4.

Jumlah folikel matur adalah jumlah seluruh folikel yang dilihat dengan dengan menggunakan USG pada hari sebelum injeksi hCG dengan diameter $\geq 17 \mathrm{~mm}$. Memberikan respon baik apabila didapatkan $\geq 3$ folikel matur dan respon buruk apabila didapatkan $<3$ folikel matur.

\section{Uji Statistik dan Analisis Data}

Data yang sudah dihimpun dikelola dan dianalisis dengan bantuan program SPSS seri 16. Tingkat kemaknaan yang digunakan pada penelitian ini adalah $95 \%$ (nilai $p<0,05$ ). Analisis data menggunakan langkah sebagai berikut: analisis univariat, analisis bivariat dimana Uji statistik yang digunakan adalah T-test atau Chi-square, dan analisis multivariat dengan menggunakan analisis regresi logistik.

\section{HASIL DAN PEMBAHASAN}

Dalam penelitian ini didapatkan 70 wanita peserta program fertilisasi in vitro (FIV) memenuhi kriteria inklusi dan eksklusi. Subyek penelitian tersebut dibagi menjadi dua kelompok yakni kelompok kadar LH $\leq 3 \mathrm{mIU} / \mathrm{ml}$ sebanyak 35 wanita sebagai kelompok terpapar dan kelompok kadar LH >3 mIU/ml sebanyak 35 wanita sebagai kelompok kontrol.
Tabel 1. Karakteristik subyek penelitian program FIV

\begin{tabular}{|c|c|c|}
\hline Karakteristik & $\mathrm{N}=70$ & $\%$ \\
\hline \multicolumn{3}{|l|}{ Usia } \\
\hline - >37 tahun & 16 & $22,86 \%$ \\
\hline - £37 tahun & 54 & $77,14 \%$ \\
\hline \multicolumn{3}{|l|}{ IMT } \\
\hline$\cdot>25 \mathrm{~kg} / \mathrm{m}^{2}$ & 34 & $48,57 \%$ \\
\hline - $f 25 \mathrm{~kg} / \mathrm{m}^{2}$ & 36 & $51,43 \%$ \\
\hline Lama infertilitas (tahun) & $6(0,5-25)$ & \\
\hline \multicolumn{3}{|l|}{ Penyebab infertil } \\
\hline - Tuba & 2 & $2,86 \%$ \\
\hline - Suami & 17 & $24,29 \%$ \\
\hline - Penyakit lain & 7 & $10 \%$ \\
\hline - Mixed & 40 & $57,14 \%$ \\
\hline - Unexplained & 4 & $5,71 \%$ \\
\hline \multicolumn{3}{|l|}{ FSH basal } \\
\hline$\cdot>7,5 \mathrm{mlU} / \mathrm{ml}$ & 24 & $34,29 \%$ \\
\hline - $f 7,5 \mathrm{mlU} / \mathrm{ml}$ & 46 & $65,71 \%$ \\
\hline \multicolumn{3}{|l|}{$E_{2}$ basal } \\
\hline • $>30 \mathrm{pg} / \mathrm{ml}$ & 35 & $50 \%$ \\
\hline - $£ 30 \mathrm{pg} / \mathrm{ml}$ & 35 & $50 \%$ \\
\hline \multicolumn{3}{|l|}{ Protokol } \\
\hline - Panjang & 22 & $31,43 \%$ \\
\hline - Pendek & 48 & $68,37 \%$ \\
\hline
\end{tabular}

Tabel 1 menunjukkan karakteristik dasar subyek penelitian program FIV. Proporsi usia subyek penelitian >37 tahun sebesar $22,86 \%$ dan $£ 37$ tahun sebesar $77,14 \%$ dengan usia termuda 22 tahun dan tertua 46 tahun. Dan yang memiliki IMT $>25 \mathrm{~kg} / \mathrm{m}^{2}$ sebanyak $48,57 \%$. Lama infertilitas bervariasi dari 0,5 tahun sampai 25 tahun, dengan reratanya adalah 6 tahun. Penyebab infertil terbanyak adalah campuran dari berbagai faktor, yaitu faktor suami, faktor tuba, dan adanya penyakit lain, yaitu sebesar $57,14 \%$. Dari seluruh sampel didapatkan 22 $(31,4 \%)$ menggunakan protokol panjang dan 48 $(68,6 \%)$ menggunakan protokol pendek. 
Tabel 2. Komparabilitas antara kelompok penelitian program FIV

\begin{tabular}{|c|c|c|c|}
\hline \multirow{2}{*}{ Variabel } & LHf3 & LH $>3$ & \multirow{2}{*}{$p$} \\
\hline & $\mathrm{N}=35$ & $\mathrm{~N}=35$ & \\
\hline Usia (tahun) & $34,09 \pm 4,032$ & $33,77 \pm 4,809$ & 0,344 \\
\hline IMT (kg/m2) & $24,73 \pm 4,49$ & $24,37 \pm 4,44$ & 0,156 \\
\hline $\begin{array}{l}\text { SOPK } \\
\text { Endometriosis 3-4 }\end{array}$ & $\begin{array}{c}3(8,6 \%) \\
6(17,1 \%)\end{array}$ & $\begin{array}{c}6(17,1 \%) \\
15(42,9 \%)\end{array}$ & $\begin{array}{l}0,288 \\
0,02 *\end{array}$ \\
\hline $\begin{array}{l}\text { - } \mathrm{FSH} \text { basal }(\mathrm{mlU} / \mathrm{ml}) \\
\text { - } \mathrm{E}_{2} \text { basal }(\mathrm{pg} / \mathrm{ml})\end{array}$ & $\begin{array}{c}6,97 \pm 2,29 \\
30,75(5-301)\end{array}$ & $\begin{array}{c}6,77(3,63-17,13) \\
29,21(9,17-193,9)\end{array}$ & $\begin{array}{l}0,617 \\
0,812\end{array}$ \\
\hline $\begin{array}{l}\text { Protokol } \\
\text { - Panjang } \\
\text { - Pendek }\end{array}$ & $\begin{array}{l}11(31,4 \%) \\
24(68,6 \%)\end{array}$ & $\begin{array}{l}11(31,4 \%) \\
24(68,6 \%)\end{array}$ & \\
\hline Dosis rFSH (IU) & $2297,43 \pm 785,59$ & $2250(900-5850)$ & 0,208 \\
\hline Durasi rFSH (hari) & $9(4-19)$ & $10(6-22)$ & 0,458 \\
\hline
\end{tabular}

Keterangan: *Bermakna $(p<0,05)$

Tabel 2 menunjukkan komparabilitas antara kelompok penelitian program FIV. Hasil komparabilitas antar kelompok penelitian menunjukkan perbedaan bermakna antara dua kelompok ditemukan pada pengaruh adanya penyakit lain yaitu endometriosis grade 3-4 dengan $p=0,02$. Tidak didapatkan perbedaan yang bermakna dalam hal usia, indeks massa tubuh, adanya penyakit lain yaitu SOPK, kadar hormon FSH basal dan estradiol basal, dosis dan durasi pemberian rFSH. Dari tabel diatas juga dapat dilihat jumlah subyek yang menderita penyakit lain yaitu SOPK sebanyak 9 (12,86\%) dan endometriosis grade 3-4 sebanyak $21(30 \%)$.

Tabel 3 menunjukkan hasil analisis bivariat variabel bebas dengan variabel tergantung. Dapat dilihat bahwa kadar $\mathrm{LH} \leq 3 \mathrm{mIU} / \mathrm{ml}$ berbeda bermakna dibandingkan kadar $\mathrm{LH}>3 \mathrm{mlU} / \mathrm{ml}$ terhadap respon stimulasi ovarium (RR 1,875; IK $95 \% 1,275-2,757 ; p=0,00 *)$.

Tabel 3. Analisis bivariat kadar hormon LH basal terhadap respon stimulasi ovarium

\begin{tabular}{|c|c|c|c|c|c|c|}
\hline \multirow{2}{*}{ Variabel } & \multirow{2}{*}{ Respon buruk } & \multirow{2}{*}{ Respon baik } & \multirow{2}{*}{$\%$} & \multicolumn{2}{|c|}{ Statistik } & \multirow{2}{*}{$p$} \\
\hline & & & & RR & IK 95\% & \\
\hline $\mathrm{LH} \leq 3(\mathrm{mlU} / \mathrm{ml})$ & 30 & 5 & $85,7 \%$ & 1,875 & $1,275-2,757$ & $0,00 *$ \\
\hline $\mathrm{LH}>3(\mathrm{mlU} / \mathrm{ml})$ & 16 & 19 & $45,7 \%$ & & & \\
\hline
\end{tabular}

Keterangan: *Bermakna $(p<0,05)$

Artinya bahwa apabila $\mathrm{LH} \leq 3 \mathrm{mIU} / \mathrm{ml}$ akan memiliki peluang sebesar 1,875 kali memberikan respon buruk dibandingkan $\mathrm{LH}>3 \mathrm{mIU} / \mathrm{ml}$.

Tabel 4 menggambarkan hubungan antara variabel tergantung dengan variabel luar. Hasil dari komparabilitas menunjukkan perbedaan tidak bermakna dalam hal mempengaruhi respon terhadap stimulasi ovarium, yaitu IMT, adanya penyakit SOPK, adanya penyakit endometriosis grade $3-4$, kadar hormon FSH 
basal, kadar hormon E2 basal, jenis protokol stimulasi, serta dosis dan durasi pemberian rFSH yang diperlukan. Dari hasil analisis tersebut diatas dapat disimpulkan bahwa tidak dapat dilakukan analisis multivariat. Jadi variabel luar tidak mempengaruhi variabel bebas dan variabel tergantung.

Tabel 4. Analisis bivariat terhadap respon stimulasi ovarium

\begin{tabular}{|c|c|c|c|c|c|}
\hline \multirow{2}{*}{ Variabel } & \multirow{2}{*}{ Respon buruk } & \multirow{2}{*}{ Respon baik } & \multicolumn{3}{|c|}{ Statistik } \\
\hline & & & RR & IK 95\% & $p$ \\
\hline \multicolumn{6}{|l|}{ IMT $\left(\mathrm{kg} / \mathrm{m}^{2}\right)$} \\
\hline$\cdot>25$ & 22 & 12 & 0,971 & $0,691-1,362$ & 0,863 \\
\hline$\cdot \leq 25$ & 24 & 12 & & & \\
\hline \multicolumn{6}{|l|}{ SOPK } \\
\hline - Ya & 7 & 2 & 1,217 & $0,818-1,809$ & 0,340 \\
\hline - Tidak & 39 & 22 & & & \\
\hline \multicolumn{6}{|c|}{ Endometriosis 3-4 } \\
\hline • Ya & 11 & 10 & 0,733 & $0,47-1,144$ & 0,124 \\
\hline - Tidak & 35 & 14 & & & \\
\hline \multicolumn{6}{|c|}{ FSH Basal (mIU/ml) } \\
\hline$\cdot>7,5$ & 14 & 10 & 0,839 & $0,569-1,237$ & 0,347 \\
\hline$\cdot \leq 7,5$ & 32 & 14 & & & \\
\hline \multicolumn{6}{|l|}{ E2 basal (pg/ml) } \\
\hline •>30 & 21 & 14 & 0,84 & $0,597-1,183$ & 0,314 \\
\hline$\cdot \leq 30$ & 25 & 10 & & & \\
\hline \multicolumn{6}{|l|}{ Protokol } \\
\hline - Panjang & 14 & 8 & 0,955 & $0,657-1,387$ & 0,804 \\
\hline - Pendek & 32 & 16 & & & \\
\hline \multicolumn{6}{|l|}{ Dosis rFSH (IU) } \\
\hline$\cdot>3000$ & 8 & 4 & 1,018 & $0,654-1,582$ & 0,61 \\
\hline$\cdot \leq 3000$ & 38 & 20 & & & \\
\hline \multicolumn{6}{|c|}{ Durasi rFSH (hari) } \\
\hline$\cdot \geq 8,5$ & 30 & 15 & 1,042 & $0,727-1,492$ & 0,822 \\
\hline$\cdot<8,5$ & 16 & 9 & & & \\
\hline
\end{tabular}

Pada penelitian ini didapatkan bahwa karakteristik pada kedua kelompok penelitian adalah sama. Tidak didapatkan perbedaan yang bermakna dalam hal usia, indeks massa tubuh, kadar FSH basal dan kadar estradiol basal.

Indeks massa tubuh pada kedua kelompok penelitian terhadap respon stimulasi hasilnya tidak berbeda bermakna yaitu didapatkan RR 0,971 dengan $p=0,863$. Pada obesitas, biasanya ditemukan kadar LH basal yang tinggi. Hal ini sesuai dengan penelitian yang menunjukkan bahwa peningkatan IMT tidak akan mempengaruhi respon terhadap stimulasi ovarium. ${ }^{5}$ Dan IMT tidak akan memberikan efek negatif pada luaran FIV. Dan hubungan antara berat badan dan infertilitas karena disovulasi dengan risiko relatif 2,1 (IK 95\% 1,0 - 4,3) pada pasien dengan berat badan sama atau melebihi $120 \%$ berat idealnya. ${ }^{6}$ 


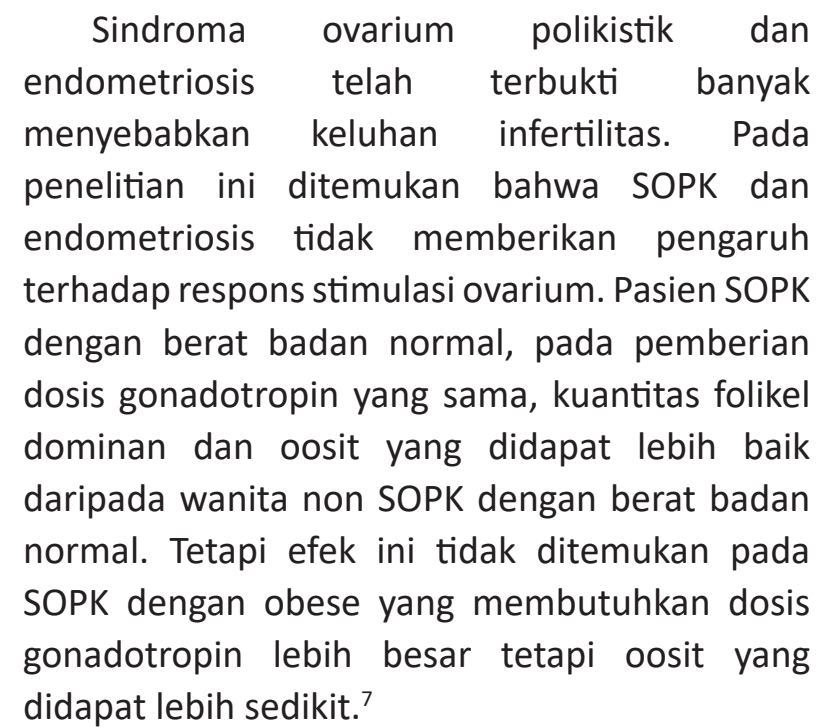

Kadar hormon basal (FSH dan E2) normal yang diperiksa pada hari kedua sampai hari keempat menstruasi secara klinis meningkatkan luaran jumlah oosit matur dibandingkan kadar hormon basal abnormal. Beberapa penelitian menunjukkan cut off point yang berbeda-beda, namun pada intinya kadar FSH basal yang rendah menunjukkan folikulogenesis yang normal karena sekresi FSH akan semakin meningkat seiring dengan penurunan cadangan ovarium. Sebuah penelitian terhadap 207 wanita yang mengikuti program FIV dengan batas FSH $<10 \mathrm{mIU} / \mathrm{ml}$ didapatkan peningkatan jumlah oosit matur. ${ }^{8}$

Peningkatan kadar estradiol basal dapat menunjukkan berkurangnya cadangan ovarium atau dapat diinterpretasikan adanya jumlah folikel yang banyak seperti pada sindroma polikistik ovarium. Apabila cadangan ovarium menurun maka kadar estradiol akan meningkat dikarenakan proses folikulogenesis terjadi terlalu cepat, tetapi peningkatan estradiol pada polikistik ovarium terjadi karena banyaknya folikel anthral yang masing-masing folikel anthral tersebut dapat menghasilkan estradiol. ${ }^{9}$ Sebuah penelitian retrospektif mengenai hubungan kadar pemeriksaan estradiol basal terhadap angka pembatalan siklus FIV pada 2624 wanita menunjukkan bahwa kadar estradiol basal $<20$ $\mathrm{pg} / \mathrm{ml}$ atau $>80 \mathrm{pg} / \mathrm{ml}$ mempunyai risiko yang lebih tinggi terhadap pembatalan siklus FIV. ${ }^{10}$

Stimulasi ovarium yang digunakan pada penelitian ini adalah metode protokol panjang dan GnRH antagonis. Dalam penelitian ini jumlah subyek yang menggunakan protokol GnRH antagonis lebih banyak (48; 68,6\%) daripada yang menggunakan protokol panjang $(22 ; 31,4 \%)$. Tidak terdapat perbedaan dosis dan durasi pemberian GnRH terhadap respon stimulasi ovarium.

Kadar LH $\leq 3 \mathrm{mIU} / \mathrm{ml}$ memiliki respon ovarium yang berbeda bermakna dibandingkan kadar LH >3 mIU/ml (RR 1,875; IK 95\% 1,275$2,757 ; p=0,00 *)$. Jadi apabila kadar LH basal $\leq 3$ $\mathrm{mIU} / \mathrm{ml}$ akan memiliki peluang sebesar 1,875 kali memberikan respon buruk dibandingkan LH $>3 \mathrm{mlU} / \mathrm{ml}$. Hasil ini sesuai dengan penelitian bahwa serum basal LH yang rendah $<3 \mathrm{mIU} / \mathrm{ml}$ dapat memprediksi penurunan respon stimulasi ovarium sebagai akibat dari penurunan estradiol puncak dan jumlah folikel preovulatori yang rendah. ${ }^{11}$

\section{KESIMPULAN DAN SARAN}

Kadar hormon LH basal yang rendah $(\leq 3$ $\mathrm{mlU} / \mathrm{ml}$ ) memberikan respon buruk pada pasien yang dikerjakan stimulasi ovarium pada program fertilisasi in vitro. Kadar hormon LH basal dapat digunakan sebagai prediktor terhadap keberhasilan stimulasi ovarium. Pada penelitian ini didapatkan $p=0,001$ yang artinya kadar hormon LH basal berpengaruh secara bermakna terhadap hasil stimulasi ovarium pada program fertilisasi in vitro.

Sebaiknya dilakukan penelitian mengenai pengaruh kadar hormon basal terhadap stimulasi ovarium dengan metode uji klinis acak terkontrol untuk mendapatkan hasil yang lebih baik. 


\section{DAFTAR PUSTAKA}

1. Bullent, Bulbul Y, Onvutral A, Yorukogiu K, Posaci C, Demir N. 1999. Accuracy of Ovarian Reserve Test. Human reproduction, 15: 2822-2826

2. Speroff L, Glass RH, Kase NG. 1999. Clinical Gynecologic Endocrinologic and Infertility, 6th rev. ed. USA: Lippicott Williams \& Wilkins, 1216-1234

3. Noci I, Biagiotti R, Maggi M, Ricci F, Cinotti A, Scarselli G. 2000. Effect of Low Day 3 Luteinizing Hormone Levels on in Vitro Fertilization Treatment Outcome. Gynecol Endocrinol, 14(5): 321-26.

4. Prasad S, Gupta T, Divya A. 2013. Correlation od the Day $3 \mathrm{FSH} / \mathrm{LH}$ Ratio and LH Concentration in Predicting IVF Outcome. J Reprod Infertil; 14(1): 2328

5. Sathya A, Balasubramanyam S, Gupta S, Verma T. 2010. Effect of body mass index on in vitro fertilization outcomes in women. J Hum Reprod Sci, 3(3):135-138.

6. Green BB, Weiss NS, Danling JR. 1988. Risk of ovulatory infertility in relation to body weight. Fertil Steril, 50:721-726.
7. McCormick B, Thomas M, Maxwell R, Williams D, Aubuchon M. 2008. Effects of polycystic ovarian syndrome on in vitro fertilization-embryo transfer outcomes are influenced by body mass index. Fertil Steril, 90(6): 2304-2309.

8. Karimzadeh MA, Ghandi S. 2009. Age and Basal FSH as a Predictor of ART Outcome. Iranian Journal of Reproductive Medicine, 7(1): 19-22

9. Toner, James P. 2011. Ovarian Reserve, Female Age and the Chance for Successful Pregnancy. Atlanta Center for Reproductive Medicine.

10. Frattarelli, Bergh, Drews. 2000.Evaluation of Basal Estradiol Levels in Assisted Reproductive Technology Cycles. Fertil Steril, 74(3): 518-24

11. Mukherjee T, Copperman AB, Lapinski R. 1996. An Elevated Day Three Follicle-Stimulating Hormone: Luteinizing Hormone Ratio (FSH:LH) the Presense of Normal Day 3 FSH Predict a Poor Response to Controlled Ovarian Hyperstimulation. Fertil steril, 65: 588-593 